\title{
The influence of Chemical Works "Police" on chemical composition of Pinus sylvestris needles, Pleurozium schreberi and soil samples
}

\author{
Wpływ oddziaływania Zakładów Chemicznych „Police” na skład \\ chemiczny igieł Pinus sylvestris, Pleurozium schreberi i gleby
}

\begin{abstract}
* Mgr inż. Natalia Mazurkiewicz, dr hab. inż. Joanna Podlasińska, Department of Ecology, Environmental Protection and Management, West Pomeranian University of Technology, Słowackiego 17 St., 71-434 Szczecin, e-mail: natalia.mazurkiewicz@zut.edu.pl
\end{abstract}

Keywords: heavy metals, bioaccumulation, Pinus sylvestris, sulphur, soil contamination, bioindicators Słowa kluczowe: metale ciężkie, bioakumulacja, Pinus sylvestris, siarka, skażenie gleby, bioindykatory

\section{Abstract}

The aim of this study was an evaluation of the influence of Chemical Works "Police" ("Grupa Azoty") on total S, N, C, Mg, K, Ca, Na $\mathrm{Hg}, \mathrm{Pb}, \mathrm{Cd}, \mathrm{Cu}, \mathrm{Co}, \mathrm{Cr}, \mathrm{Mn}, \mathrm{Ni}$ and $\mathrm{Zn}$ concentrations in Il-year-old needles of Pinus sylvestris L., Pleurozium schreberi (Brid.) Mitt. and soil samples. The research material was collected in spring 2013 in the coniferous habitats. The total Hg content was determined by Mercury Analyzer AMA 254. The total content of S, N and $\mathrm{C}$ was analysed by COSTECH CHNS elementary analyser The total content of other elements was determined using atomic absorption spectrometer ASA iCE 3000 . The highest mercury content was similar in pine needles $\left(0.06 \mathrm{mg} \cdot \mathrm{kg}^{-1} \mathrm{~d}\right.$. w. $)$ and in moss $\left(0.07 \mathrm{mg} \bullet \mathrm{kg}^{-1} \mathrm{~d}\right.$. w.). The soil samples $\mathrm{pH}$ value was typical for rusty soils, in which the obtained $\mathrm{pH}-\mathrm{KCl}$ value was $3.13-4.39$ and $\mathrm{pH}-\mathrm{H}_{2} \mathrm{O}$ was 3.69-5.14 (extreme acid soils). The $\mathrm{Zn}, \mathrm{Pb}, \mathrm{Ni}, \mathrm{Hg}$ $\mathrm{Fe}, \mathrm{Cu}$ and $\mathrm{Cr}$ concentrations were higher in moss than in needles. The content of $\mathrm{Pb}$ in Pleurozium schreberi $\left(3.13 \mathrm{mg} \cdot \mathrm{kg}^{-1} \mathrm{~d}\right.$. w.) was few times higher than in Pinus sylvestris needles $(0.073$ $0.817 \mathrm{mg} \cdot \mathrm{kg}^{-1} \mathrm{~d}$. w.). The soil contamination with heavy metals was not observed. There has been almost a double reduction of sulphur content in pine needles and moss over last 20 years.

(C) IOŚ-PIB

\section{INTRODUCTION}

The Chemical Works "Police" (currently "Grupa Azoty") are involved in the production of mineral fertilisers including multi-mineral fertilisers, phosphoric fertilisers, nitric fertilisers and nitric-sulphuric fertilisers. Despite implementation of the Environmental Management System according to ISO 14001:2004 and new technologies of gases and particulate matter reduction in the last 10 years, the factory remains one of the main West Pomeranian environment pollutants [www.grupaazoty.com; Raport....2010-2011]. The emission of sulphur oxides, nitrogen oxides, fluorine, volatile organic compounds and particulate matter (i. e. heavy metals) may have a negative impact on flora living in the pollutant area [Bell and Treshow, 2004]. Heavy metals are particularly dangerous for the environment because of their ability to accumulate in several ways. They cannot be decomposed by microorganisms, but are transported to other parts

\section{Streszczenie}

Celem pracy była ocena wpływu Zakładów Chemicznych „Police" S. A. (Grupa Azoty) na zawartość S, N, C, Mg, K, Ca, Na, Hg, $\mathrm{Pb}, \mathrm{Cd}, \mathrm{Cu}, \mathrm{Co}, \mathrm{Cr}, \mathrm{Mn}, \mathrm{Ni}$ i Zn ogółem w drugorocznych szpilkach sosny zwyczajnej (Pinus sylvestris), w rokietniku pospolitym (Pleurozium schreberi) oraz w glebie. Próbki pozyskano wiosna 2013 roku na siedliskach borowych. Całkowita zawartość Hg oznaczono za pomocą analizatora rtęci AMA 254. Zawartość S, N i C ogółem oznaczono analizatorem elementarnym CHNS firmy COSTECH. Zawartość pozostałych pierwiastków oznaczono spektrometrem absorpcji atomowej ASA iCE 3000. Najwyższa zawartość rtęci w szpilkach sosny $\left(0,06 \mathrm{mg} \cdot \mathrm{kg}^{-1}\right.$ suchej masy) i w mchu $\left(0,07 \mathrm{mg} \cdot \mathrm{kg}^{-1}\right.$ suchej masy) była podobna. Wartości $\mathrm{pH}$ gleby były charakterystyczne dla gleb rdzawych i wynosiły: $\mathrm{pH}-\mathrm{KCl} 3,13-4,39$; $\mathrm{pH}-\mathrm{H}_{2} \mathrm{O}$ 3,69-5,14 (gleby silnie kwaśne). Zawartość Zn, Pb, Ni, Hg, $\mathrm{Fe}, \mathrm{Cu}$ i Cr była wyższa w mchu niż w szpilkach sosny. Zawartość $\mathrm{Pb}$ w mchu $\left(3,13 \mathrm{mg} \cdot \mathrm{kg}^{-1} \mathrm{~s}\right.$. m.) była kilka razy wyższa niż w szpilkach Pinus sylvestris $\left(0,073-0,817 \mathrm{mg} \cdot \mathrm{kg}^{-1} \mathrm{~s} . \mathrm{m}\right.$.). Nie stwierdzono zanieczyszczenia gleb metalami ciężkimi. Stwierdzono prawie dwukrotną redukcję w akumulacji siarki w szpilkach sosny oraz w mchu na przestrzeni ostatnich 20 lat. of the environment. Unfortunately, heavy metals accumulate in plants or animals organisms, which are the elements of the food chain, and they can slowly damage the internal organs [Manahan, 2013].

Pinus sylvestris belongs to the group of plants vulnerable to the $\mathrm{SO}_{2}$, $\mathrm{O}_{3}$ and $\mathrm{F}$ pollution, what can be seen in affected needles necrosis and progressive defoliation of trees. Mosses are good bioindicators of air pollution with heavy metals, primarily due to the absorption of atmospheric pollutants by the entire surface of the thallus and bioaccumulation potential over many years [Zimny, 2006].

The main purpose of this study is to evaluate the impact of Chemical Works "Police" on the chemical composition of Pinus sylvestris L. Il-year-old needles, Pleurozium schreberi (Brid.) Mitt. moss and soil samples collected from coniferous habitats within the factory affected area. 


\section{MATERIAL AND METHODS}

The samples of Pinus sylvestris II-year-old needles, soil and Pleurozium schreberi were collected in spring 2013 from Chemical Works "Police" influence area, which is one of the main Polish producer of fertilisers. Namely, seven pooled needles samples, consisting of at least 300 needles and obtained from five trees in each point, were collected in forest sites of Wieńkowo, Witorza, Trzeszczyn, Jasienica and Tanowo villages and two samples were collected in Police town (Fig. 1). The needles were collected from bottom branches of the trees, located on the outer wall of the forest. The soil samples were also collected in every point of research using Egner's sampling stick (approximately $100 \mathrm{~g}$ from 0 to $20 \mathrm{~cm}$ depth - O, A or O, AE horizons). The soil substrate was characterised as mineral. The Pleurozium schreberi samples were collected from the adjacent area of every research point.

Pinus sylvestris needles, moss and soil samples were dried in temperature up to $40^{\circ} \mathrm{C}$ and pulverised in laboratory mill or mortar. The sub-samples of needles and moss $(1.0 \mathrm{~g})$ were cold-treated with oxi-acidic mixture of $65 \% \mathrm{HNO}_{3}$ and $30 \% \mathrm{H}_{2} \mathrm{O}_{2}$ (4 and $1 \mathrm{ml}$, respectively) and after at least 12 hours digestion put in Milestone ${ }^{\mathrm{TM}}$ microwave oven. Whereas, soil samples $(0.5 \mathrm{~g})$ were cold-treated with $6 \mathrm{ml}$ mixture of $5: 1$ concentrated acids $\mathrm{HNO}_{3}: \mathrm{HClO}_{4}(65: 60 \%$, respectively) and also mineralised with Milestone ${ }^{\mathrm{TM}}$ microwave oven. Mineralised samples were finally diluted to $25 \mathrm{ml}$ with deionised water. The content of $\mathrm{Cd}, \mathrm{Cu}, \mathrm{Cr}, \mathrm{Mn}, \mathrm{Ni}, \mathrm{Co}, \mathrm{Pb}, \mathrm{Mg}, \mathrm{Na}, \mathrm{Ca}$, $\mathrm{Fe}, \mathrm{Zn}$ and $\mathrm{K}$ in dry weight (d. w.) of needles, moss and soil samples was determined using atomic absorption spectrometer ASA iCE 3000 series. The determination process was validated with certified reference materials: tea leaves (INCT-TL-1) produced by Institute of Nuclear Chemistry and Technology Warsaw, Poland and loamy sand (CRM 036-050).

The content of $\mathrm{Hg}$ was determined directly in dried samples using AMA 254 Mercury Analyzer. The content of $P$ was determined with spectrometric molybdenum blue method (690 nm wave length).
The $\mathrm{pH}$ in $1 \mathrm{M} \mathrm{KCl}$ and $\mathrm{H}_{2} \mathrm{O}$, and electrical conductivity of soil samples were determined using automatic conductivity meter.

The limits of detection $\left(\mathrm{mg} \cdot \mathrm{kg}^{-1}\right)$ for determined elements were as follows: Cd 0.013; Cu 0.005; Cr 0.005; Mn 0.002; Ni 0.008; Co 0.010; Pb 0.073; Mg 0.002; Na 0.004; Ca 0.009; Fe 0.052; Zn 0.003 and $\mathrm{K} 0.001$.

Statistical analysis of the obtained data was performed using Statistica software (Statsoft Inc., version 10.0. MR1). At first, data were investigated to determine their distribution using the Shapiro-Wilks' W-test. The basic statistical analysis included arithmetic mean, standard deviation and range values (minimum and maximum values). Bioaccumulation of metals concentrations between investigated species were compared by the Mann-Whitney $U$ test $(p \leq 0.05)$. The Spearman correlation coefficients $(p \leq 0.05)$ between metals accumulation in Pinus sylvestris needles were also analysed

\section{RESULTS AND DISCUSSION}

The data of soil $\mathrm{pH}$ in $1 \mathrm{M} \mathrm{KCl}, \mathrm{pH}$ in $\mathrm{H}_{2} \mathrm{O}$ and electrical conductivity are given in Table 1. The arithmetical mean, standard deviation and range (minimum and maximum values) of determined heavy metals $(\mathrm{Pb}, \mathrm{Hg}$ and $\mathrm{Cd}$ ) and trace elements (Co, $\mathrm{Cu}, \mathrm{Cr}, \mathrm{Fe}, \mathrm{Mn}, \mathrm{Ni}$ and $\mathrm{Zn}$ ) in $\mathrm{d}$. w. with bioaccumulation factors are presented in Table 2. Macroelement results ( $\mathrm{Mg}, \mathrm{Na}, \mathrm{Ca}, \mathrm{K}, \mathrm{P}, \mathrm{N}, \mathrm{C}, \mathrm{S}$ ) are presented in Table 3. The analysis of Spearman correlation coefficients between elements in Pinus sylvestris needles are presented in Table 4.

The samples of Pinus sylvestris needles, moss and soil were collected from coniferous forests habitat. Investigated soils could be classified as Brunic Arenosol or Albic Brunic Arenosol [IUSS...2006]. The soil $\mathrm{pH}$ (in $1 \mathrm{M} \mathrm{KCl}$ and $\mathrm{H}_{2} \mathrm{O}$ ) was typical for the coniferous habitats and the range was 3.13-4.39 in $\mathrm{KCl}$ (acidic habitats) and 3.69-5.14 in $\mathrm{H}_{2} \mathrm{O}$ (extreme acidic and acidic habitats). The electrical conductivity of tested soils ranged from 22.1 to $246.8 \mu \mathrm{S} \cdot \mathrm{cm}^{-1}$, wherein the highest values were observed in soil samples from Police town. Borowiec [1990] performed soil and

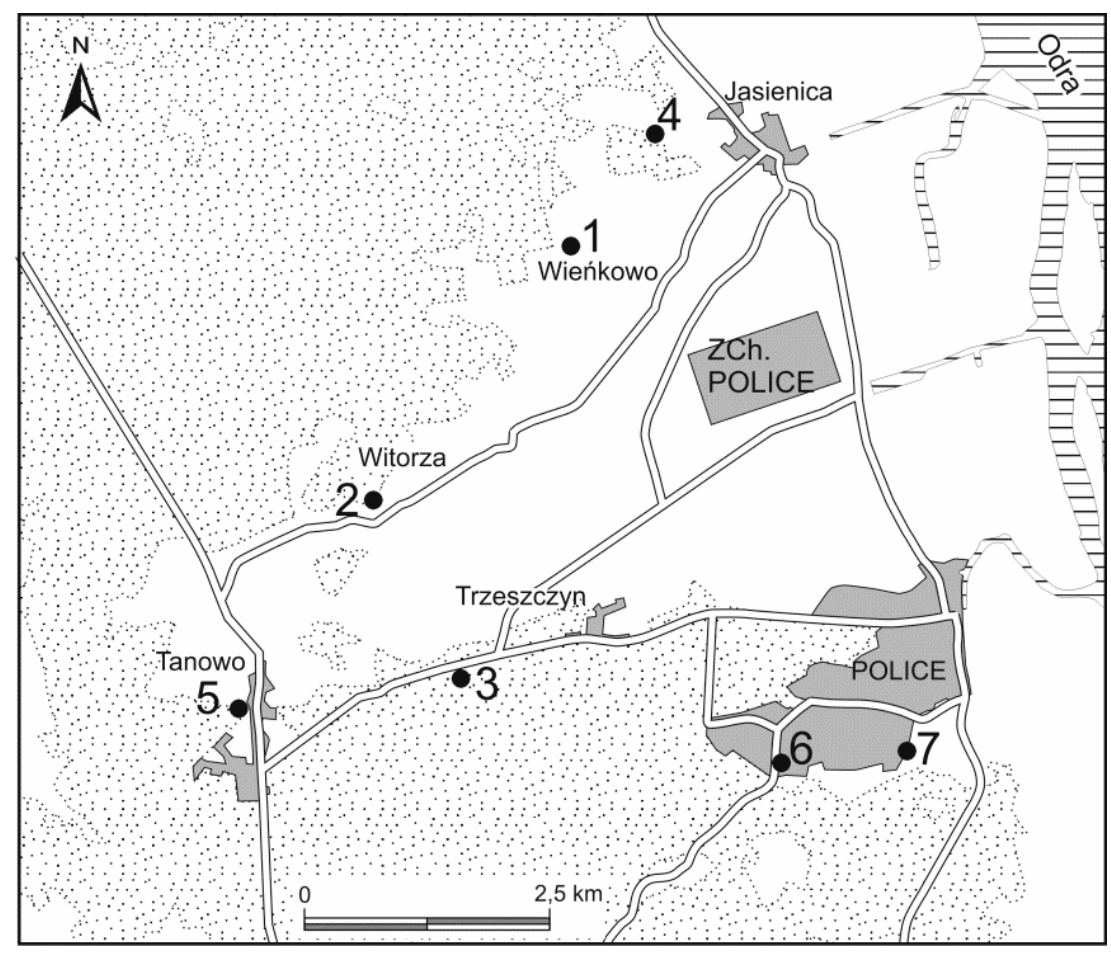

Fig. 1. Sampling area 
Table 1. The $\mathrm{pH}$ and electrical conductivity values of soil samples

\begin{tabular}{|c|c|c|c|c|}
\hline $\begin{array}{l}\text { Localisation and distance from } \\
\text { the main source of emissions }[\mathrm{km}]\end{array}$ & Number & $\mathrm{pHKCl}$ & $\mathrm{pHH}_{2} \mathrm{O}$ & $\begin{array}{c}\mathrm{EC} \\
\mu \mathrm{S} \cdot \mathrm{cm}^{-1}\end{array}$ \\
\hline Wieńkowo - 2.6 & 1 & 4.39 & 5.14 & 26.21 \\
\hline Witorza - 5.0 & 2 & 3.82 & 4.66 & 22.13 \\
\hline Trzeszczyn - 3.4 & 3 & 3.25 & 3.79 & 76.93 \\
\hline Jasienica - 2.7 & 4 & 3.99 & 4.54 & 31.03 \\
\hline Tanowo - 6.6 & 5 & 3.83 & 4.68 & 50.52 \\
\hline Police - 3.3 & 6 & 3.26 & 3.83 & 246.8 \\
\hline Police - 3.8 & 7 & 3.13 & 3.69 & 115.74 \\
\hline
\end{tabular}

pine needles experiment in 1977 and 1988 in the Chemical Works "Police" area in two points - approximately 15 and $3 \mathrm{~km}$ from the emitter. The average soil $\mathrm{pHH}_{2} \mathrm{O}$ in 1977 and 1988 was 3.4, while currently the range is about $3.69-5.14$, which shows a decrease in soil acidification.

Comparison of metals bioaccumulation in needles and moss revealed that $\mathrm{Zn}, \mathrm{Pb}, \mathrm{Ni}, \mathrm{Hg}, \mathrm{Fe}, \mathrm{Cu}$ and $\mathrm{Cr}$ concentrations were higher in moss than in needles. However, the opposite situation was observed with $\mathrm{Co}$ and $\mathrm{Mn}$ contents - they were higher in needles. The concentrations of $\mathrm{Pb}, \mathrm{Fe}, \mathrm{Cr}$ and $\mathrm{Co}$ were higher in soil samples than in plants, which can be explained by the way of elements absorption on these organisms (mosses by the entire surface of thallus from water and air, directly or by the stomatal apparatus in Pinus sylvestris needles). The $\mathrm{Cd}$ concentration in all of determined samples was under detection limit $\left(<0.013 \mathrm{mg} \bullet \mathrm{kg}^{-1} \mathrm{~d}\right.$. w. $)$. Iron content was markedly higher in needles and in soil, which is borne out by bioaccumulation factors value $(B C F N / S=10.51)$. It is noteworthy that $\mathrm{Co}$ and $\mathrm{Mn}$ were accumulated 11.03 and 9.75 times, respectively, more than their concentrations in soil.
Soil quality standards excess of any metal concentration, according to the Polish laws [Rozporządzenie...2002], (Cr 50.0; Zn 100.0; Cd 1.0; Co 20.0; Cu 30.0; Ni 35.0; Pb 50.0; $\mathrm{Hg} 0.5 \mathrm{mg} \bullet \mathrm{kg}^{-1}$ d. w.), was not observed in this study. Referring to the Geochemical Atlas of Poland [www.mapgeochem.pgi.gov.pl], the average content of sulphur in examined material $(0.004 \%)$ was lower than average content of S in total soils $(0.017 \%)$, industrial areas $(0.038 \%)$ and forest soils $(0.012 \%)$ of Poland.

There were also no statistically significant (Mann-Whitney U Test; $p \leq 0.05$ ) differences between mosses and needles bioaccumulation. Nevertheless, few statistically positive significant Spearman correlation coefficients $(p \leq 0.05)$ between metals bioaccumulation in needles were observed, e.g.: Co-Mn ( $r=0.666), \mathrm{Fe}-\mathrm{Cr}(r=0.800)$ and $\mathrm{Cu}-\mathrm{Ni}(\mathrm{r}=0.700)$

Similar studies of metals accumulation in Pinus sylvestris needles and Pleurozium schreberi were performed by many authors [Świercz, 2003; Parzych and Jonczak, 2013; Borowiec and Zabłocki, 1984; Borowiec et al., 2005; Gałuszka, 2006; Dołęgowska et al., 2013].

Table 2. The content of heavy metals and trace elements in Pinus sylvestris needles, Pleurozium schreberi and soil samples

\begin{tabular}{|c|c|c|c|c|c|c|c|c|c|c|}
\hline \multirow{3}{*}{ Object } & \multirow{2}{*}{$n=7$} & Co & $\mathrm{Cr}$ & $\mathrm{Cu}$ & $\mathrm{Fe}$ & Mn & $\mathrm{Ni}$ & $\mathrm{Pb}$ & Zn & $\mathrm{Hg}$ \\
\hline & & \multicolumn{9}{|c|}{$\mathrm{mg} \cdot \mathrm{kg}^{-1} \mathrm{~d} . \mathrm{w}$} \\
\hline & AM & 0.016 & 3.19 & 4.16 & 120.7 & 504.6 & 2.51 & 0.073 & 46.7 & 0.041 \\
\hline \multirow{4}{*}{$\begin{array}{l}\text { Pinus sylvestris } \\
\text { needles }\end{array}$} & SD & 0.279 & 4.36 & 0.81 & 58.1 & 299.8 & 2.64 & 0.665 & 10.3 & 0.011 \\
\hline & Min & 0.010 & 0.94 & 3.48 & 58.8 & 105.9 & 0.84 & 0.013 & 37.5 & 0.025 \\
\hline & Max & 0.656 & 14.64 & 6.03 & 236.1 & 900.2 & 9.40 & 0.817 & 68.1 & 0.062 \\
\hline & AM & 0.010 & 12.33 & 7.59 & 528.2 & 345.2 & 7.62 & 3.13 & 50.5 & 0.052 \\
\hline \multirow{4}{*}{ Pleurozium schreberi } & SD & 0.283 & 16.43 & 2.31 & 207.2 & 228.6 & 9.37 & 1.32 & 3.5 & 0.013 \\
\hline & Min & 0.010 & 1.62 & 4.69 & 246.1 & 102.8 & 1.86 & 1.97 & 46.5 & 0.039 \\
\hline & Max & 0.366 & 41.43 & 10.33 & 800.0 & 671.2 & 24.26 & 4.94 & 54.3 & 0.071 \\
\hline & $\mathrm{AM}$ & 0.071 & 3.98 & 3.05 & 3260.6 & 63.1 & 1.78 & 9.63 & 16.5 & 0.020 \\
\hline \multirow{3}{*}{ Soil } & SD & 0.389 & 1.21 & 1.03 & 849.8 & 54.0 & 0.80 & 12.84 & 10.7 & 0.015 \\
\hline & Min & 0.010 & 2.52 & 1.82 & 1677.7 & 26.3 & 0.44 & 2.32 & 6.2 & 0.007 \\
\hline & Max & 0.821 & 5.74 & 5.24 & 4334.9 & 201.9 & 2.69 & 43.34 & 38.4 & 0.053 \\
\hline \multirow{2}{*}{ BCFN/S } & $A M$ & 2.37 & 0.98 & 0.04 & 10.51 & 1.73 & 0.02 & 3.65 & 3.26 & 2.37 \\
\hline & SD & 5.02 & 1.60 & 0.02 & 7.89 & 1.65 & 0.04 & 1.57 & 2.59 & 5.02 \\
\hline \multirow{2}{*}{ BCFM/S } & $A M$ & 11.03 & 4.39 & 3.27 & 0.21 & 9.75 & 5.49 & 0.63 & 5.00 & 4.96 \\
\hline & SD & 15.85 & 6.76 & 1.90 & 0.16 & 9.53 & 7.86 & 0.47 & 2.46 & 3.35 \\
\hline
\end{tabular}

$\mathrm{Cd}<0.013$; d. w.-dry weight; AM-arithmetical mean; SD-standard deviation; Min-minimum value; Max-maximum value; BCFN/S-bioaccumulation factor between Pinus sylvestris needles and soil; BCFM/S-bioaccumulation factor between Pleurozium schreberi and soil 
Table 3. The content of macroelements in Pinus sylvestris needles, Pleurozium schreberi and soil samples

\begin{tabular}{|c|c|c|c|c|c|c|c|c|c|}
\hline \multirow{2}{*}{ Object } & \multirow{2}{*}{$n=7$} & Mg & $\mathrm{Na}$ & $\mathrm{Ca}$ & K & $\mathbf{P}$ & N & C & s \\
\hline & & \multicolumn{8}{|c|}{$\mathbf{g} \cdot \mathbf{k g}^{-1}$ d. $\mathbf{w}}$. \\
\hline \multirow{4}{*}{$\begin{array}{c}\text { Pinus sylvestris } \\
\text { needles }\end{array}$} & AM & 0.876 & 0.266 & 5.06 & 5.56 & 2.87 & 16.0 & 446.6 & 0.532 \\
\hline & SD & 0.198 & 0.155 & 1.78 & 1.46 & 0.722 & 2.8 & 148.8 & 0.266 \\
\hline & Min & 0.592 & 0.059 & 2.96 & 3.69 & 1.32 & 11.7 & 50.4 & 0.305 \\
\hline & Max & 1.152 & 0.502 & 8.11 & 8.10 & 3.93 & 21.2 & 511.3 & 1.184 \\
\hline \multirow{4}{*}{ Pleurozium schreberi } & AM & 1.063 & 0.143 & 1.68 & 7.32 & 4.54 & 15.1 & 428.3 & 0.736 \\
\hline & SD & 0.306 & 0.043 & 0.177 & 1.77 & 1.15 & 6.0 & 3.8 & 0.292 \\
\hline & Min & 0.728 & 0.096 & 1.40 & 5.46 & 3.07 & 10.0 & 424.2 & 0.533 \\
\hline & Max & 1.378 & 0.208 & 1.83 & 9.09 & 6.19 & 24.8 & 434.1 & 1.249 \\
\hline \multirow{4}{*}{ Soil } & AM & 0.222 & 0.578 & 0.168 & 0.601 & 0.005 & 0.636 & 11.40 & 0.044 \\
\hline & SD & 0.059 & 0.015 & 0.064 & 0.164 & 0.005 & 0.460 & 7.07 & 0.075 \\
\hline & Min & 0.119 & 0.047 & 0.109 & 0.369 & 0.001 & 0.278 & 5.93 & 0.005 \\
\hline & Max & 0.294 & 0.094 & 0.291 & 0.896 & 0.017 & 1.8 & 29.58 & 0.241 \\
\hline \multirow{2}{*}{ BCFN/S } & AM & 4.14 & 4.64 & 33.21 & 9.52 & 3034.4 & 31.23 & 48.37 & 49.26 \\
\hline & SD & 1.21 & 2.62 & 16.06 & 2.26 & 872.5 & 12.46 & 24.60 & 72.46 \\
\hline \multirow{2}{*}{ BCFM/S } & AM & 5.56 & 2.87 & 10.72 & 14.03 & 5115.0 & 39.55 & 51.47 & 87.04 \\
\hline & SD & 1.44 & 1.02 & 4.27 & 2.28 & 1858.7 & 28.19 & 13.42 & 92.30 \\
\hline
\end{tabular}

d. w.-dry weight; AM-arithmetical mean; SD-standard deviation; Min-minimum value; Max-maximum value; BCFN/S-bioaccumulation factor between Pinus sylvestris needles and soil; BCFM/S-bioaccumulation factor between Pleurozium schreberi and soil

Świercz [2003] presented a study of II-year-old needles collected from cement factory influence area in Świętokrzyskie voivodeship, Poland. Comparing the results, the differences in $\mathrm{Fe}, \mathrm{Mn}, \mathrm{Pb}, \mathrm{Na}$, $\mathrm{K}$ and $\mathrm{Ca}$ bioaccumulation were observed. The concentrations of Fe $\left(120.7 \mathrm{mg} \cdot \mathrm{kg}^{-1} \mathrm{~d}\right.$. w. $)$ and $\mathrm{Mn}\left(504.6 \mathrm{mg} \cdot \mathrm{kg}^{-1} \mathrm{~d}\right.$. w. $)$ in this research were higher than those by Świercz [2003] (94.0 and $46.0 \mathrm{mg} \cdot \mathrm{kg}^{-1} \mathrm{~d}$. w., respectively). However, the $\mathrm{Pb}$ and $\mathrm{Hg}$ contents were lower. The results of other elements were comparable. The received findings of II-year-old Pinus sylvestris needles correspond to the research by Parzych and Jonczak [2013] at Słowiński National Park in Poland, but there is a significant difference in $\mathrm{Mn}$ accumulation. Namely, the range of $\mathrm{Mn}$ in conducted study is 105.9-900.2 $\mathrm{mg} \cdot \mathrm{kg}^{-1} \mathrm{~d}$. w., while in Słowiński NP the range was not as wide (211.1-449 $\mathrm{mg} \cdot \mathrm{kg}^{-1} \mathrm{~d}$. w.) [Parzych and Jonczak, 2013]. Borowiec and Zabłocki [1984] and Borowiec et al. [2005] conducted the Pinus sylvestris needles sulphur accumulation tests at the same area of Chemical Works "Police" in 1984-2000. The average content of $\mathrm{S}$ in Pinus sylvestris needles in 1984 had been 1.9$2.1 \mathrm{~g} \cdot \mathrm{kg}^{-1} \mathrm{~d}$. $\mathrm{w}$. and it progressively decreased to $1.2-1.5 \mathrm{~g} \cdot \mathrm{kg}^{-1}$ d. w. in $1980-1989$ and $0.9-1.1 \mathrm{~g} \mathrm{~kg}^{-1} \mathrm{~d}$. w. in 2000 [Borowiec and Zabłocki, 1984; Borowiec et al., 2005]. The average concentration of $\mathrm{S}$ in Pleurozium schreberi collected from the fertilisers factory influence area in 1984 was in the range of $2.6-3.6 \mathrm{~g} \cdot \mathrm{kg}^{-1}$ d. w. [Borowiec and Zabłocki, 1984]. Based on the results of other authors mentioned above, it can be concluded that there has been a significant improvement in the level of sulphur accumulation in Pinus sylvestris needles from the Chemical Works "Police" influence area.

The investigation of sulphur content in pine needles within 0.5$7.7 \mathrm{~km}$ from Lucchini smelter in Warsaw [Dmuchowski and Czwakiel, 2005] also showed that the negative influence of Chemical
Works "Police" is less. Furthermore, according to Huttunen et al [1985], the harmful level of sulphur for plants $\left(1.2 \mathrm{~g} \cdot \mathrm{kg}^{-1}\right)$ has not been exceeded.

Gałuszka [2006] presented the findings of Fe $\left(304-1289 \mathrm{mg} \cdot \mathrm{kg}^{-1}\right.$ d. w.), $\mathrm{Hg}\left(0.05-0.123 \mathrm{mg} \cdot \mathrm{kg}^{-1} \mathrm{~d}\right.$. w.), Mn (124.0-837.0 $\mathrm{mg} \cdot \mathrm{kg}^{-1}$ d. w.), $\mathrm{Pb}\left(<5.0-11 \mathrm{mg} \cdot \mathrm{kg}^{-1}\right.$ d. w.) and $\mathrm{Zn}\left(36-52 \mathrm{mg} \cdot \mathrm{kg}^{-1}\right.$ d. w. $)$ accumulation in Pleurozium schreberi from Wigierski National Park in Poland, comparable with the results obtained in this study. In turn, Dołęgowska et al. [2013] performed research from the Kielce area, which included $\mathrm{Cd}, \mathrm{Co}, \mathrm{Hg}, \mathrm{Mn}, \mathrm{Ni}, \mathrm{Pb}$ and $\mathrm{Zn}$ concentrations in Pleurozium schreberi. A substantial part of the results of $\mathrm{Cu}\left(6.75-15.46 \mathrm{mg} \cdot \mathrm{kg}^{-1} \mathrm{~d}\right.$. w.), Fe $\left(406.0-753.0 \mathrm{mg} \cdot \mathrm{kg}^{-1}\right.$ d. w.), Mn (35.0-697.0 mg $\mathrm{kg}^{-1}$ d. w.), $\mathrm{Hg}\left(0.028-0.078 \mathrm{mg} \cdot \mathrm{kg}^{-1}\right.$ d. w.) and $\mathrm{Zn}\left(45.0-81.0 \mathrm{mg} \cdot \mathrm{kg}^{-1}\right)$ was comparable with findings of our study. However, the contents of $\mathrm{Cd}\left(0.38-1.06 \mathrm{mg} \cdot \mathrm{kg}^{-1}\right.$ d. w.), Co (0.20-0.65 $\mathrm{mg} \cdot \mathrm{kg}^{-1} \mathrm{~d}$. w.) and $\mathrm{Pb}\left(8.3-21.5 \mathrm{mg} \cdot \mathrm{kg}^{-1}\right.$ d. w.) in Pleurozium schreberi from Kielce area were higher than those observed from Police area. Merely one element concentration (Ni-7.62 $\mathrm{mg} \cdot \mathrm{kg}^{-1} \mathrm{~d}$. w.) was clearly higher in moss samples from this study than in samples from Dołęgowska et al. [2013] $\left(1.0-2.2 \mathrm{mg} \cdot \mathrm{kg}^{-1} \mathrm{~d}\right.$. w.).

\section{CONCLUSIONS}

A significant improvement of sulphur accumulation in Pinus sylvestris needles and Pleurozium schreberi over many years was observed. The situation can be related to reduction of pollutants emission and implementation of new technologies by Chemical Works "Police". Pleurozium schreberi accumulated metals in a higher level than II-year-old needles. The soil contamination with heavy metals was not observed within the studied area. 
Table 4. Metal-to-metal Spearman correlation coefficients in Pinus sylvestris needles

\begin{tabular}{|c|c|c|c|c|c|c|c|}
\hline & Co & Cr & $\mathbf{C u}$ & $\mathbf{F e}$ & $\mathbf{M n}$ & $\mathbf{N i}$ & $\mathbf{P b}$ \\
\hline $\mathbf{C r}$ & -0.250 & & & & & \\
\hline $\mathbf{C u}$ & 0.367 & 0.517 & & & & \\
\hline $\mathbf{F e}$ & -0.100 & $0.800^{*}$ & 0.550 & & & \\
\hline $\mathbf{M n}$ & $0.667^{*}$ & -0.650 & -0.167 & -0.567 & & \\
\hline $\mathbf{N i}$ & 0.133 & 0.617 & $0.700^{*}$ & 0.617 & -0.117 & & \\
\hline $\mathbf{P b}$ & 0.383 & -0.483 & -0.567 & -0.283 & 0.567 & -0.200 & \\
\hline $\mathbf{Z n}$ & -0.250 & -0.150 & -0.250 & 0.033 & -0.383 & -0.417 & 0.067 \\
\hline $\mathbf{H g}$ & 0.317 & 0.617 & 0.317 & 0.400 & -0.283 & 0.233 & 0.017 \\
\hline
\end{tabular}

*Significant with $p \leq 0.05$

\section{REFERENCES AND LEGAL ACTS}

BELL J. N., TRESHOW M. 2004. Zanieczyszczenie powietrza a życie roślin. WNT, Warszawa.

BOROWIEC S. 1990. Zmiany w chemizmie opadów, gleb, cieków na obszarach leśnych pozostających pod wpływem emisji przemysłowych na Pomorzu Zachodnim. Zesz. Nauk. AR Szczecin, Roln. 141: 19-29.

BOROWIEC S., ZABŁOCKI Z. 1984. Zawartość fluoru i siarki w mchach i szpilkach sosny pospolitej jako wskaźnik skażenia środowiska leśnego przez Zakłady Chemiczne „Police”. II Krajowe Sympozjum. Reakcje biologiczne drzew na zanieczyszczenia przemysłowe, 16-19 maja 1984 r., Kórnik.

BOROWIEC S., ZABŁOCKI Z., LEŚNIK T., CEDRO A., 2005. Ocena wpływu zanieczyszczeń emitowanych przez Zakłady Chemiczne „Police” w latach 1969-2000 na roczne przyrosty sosny zwyczajnej na wybranych powierzchniach w Puszczy Wkrzańskiej na terenie Nadleśnictwa Trzebież. Część I: Ilość związków siarki i fluoru docierająca z opadem oraz akumulowana w szpilkach sosny. Folia Univ. Agric. Stetin. Agricultura 244, 99: 23-29.

Dmuchowski W., Czwakiel E. 2005. Ocena stopnia zanieczyszczenia środowiska siarką i ołowiem w pobliżu źródła emisji, na podstawie określenia ich akumulacji w igłach sosny zwyczajnej. Zeszyty Problemowe Postępów Nauk Rolniczych. 505: 89-94.

DOŁĘGOWSKA S., MIGASZEWSKI Z. M., MICHALIKA. 2013. Hylocomium splendens (Hedw.) B. S. G. and Pleurozium schreberi (Brid.) Mitt. as trace element bioindicators: Statistical comparison of bioaccumulative properties. J. Environ. Sci. 2. 2: 340-347.

GAŁUSZKA A. 2006. Geochemical background of selected trace elements in mosses Pleurozium schreberii (Brid.) Mitt. and
Hylocomium splendens (Hedw.) B. S. G. from Wigierski National Park. Pol. J. Environ. Stud. 15, 2a: 72-77.

HUTTUNEN S., LEINE K., TORVELA H. 1985. Seasonal sulfur contents of pine Needles as indices of air pollution. Ann. Bot. Fennici. 22: 343-359.

IUSS Working Group WRB. 2006. World Reference Base for Soil Resources. 2nd edition. World Soil Resources Reports No. 103. FAO, Rome: 132.

MANAHAN S. E. 2013. Toksykologia środowiska. Aspekty chemiczne i biochemiczne. PWN. Warszawa.

PARZYCH A., JONCZAK J. 2013. Content of heavy metals in needles of scots pine (Pinus sylvestris L.) in selected pine forests in Słowiński National Park. Arch. Environ. Prot. 39, 1: 41-51.

Raport o stanie środowiska w województwie zachodniopomorskim w latach 2010-2011. Rozdział VI: Ochrona powietrza, WIOŚ, Szczecin.

Rozporządzenie Ministra Środowiska z dnia 9 września 2002 r. w sprawie standardów jakości gleby oraz standardów jakości ziemi (Dz. U. nr 165, poz. 1359).

ŚWIERCZ A. 2003. Zawartość pierwiastków metalicznych w glebie, igliwiu i korze sosny po zmniejszeniu imisji alkalicznej. Reg. Monit. Środ. Przyrod. 4:107-113.

\section{www.grupaazoty.com}

www.mapgeochem.pgi.gov.pl/poland/index.html - Geochemical Atlas of Poland.

ZIMNY H. 2006. Ekologiczna ocena stanu środowiska. Bioindykacja i biomonitoring. Agencja Reklamowo-Wydawnicza Arkadiusz Grzegorczyk, Warszawa. 